\title{
KEEFEKTIFAN MODEL PEMBELAJARAN BERBASIS PROYEK DALAM KETERAMPILAN BERBICARA BAHASA JERMAN SISWA KELAS X MIA SMA NEGERI 2 SUNGGUMINASA
}

\author{
Zulhana $^{1}$ dan Misnawaty Usman ${ }^{2}$ \\ Fakultas Bahasa dan Sastra, Universitas Negeri Makassar \\ E-mail ${ }^{1}$ : hana.jasumin@gmail.com
}

\begin{abstract}
ABSTRAK
Penelitian ini dilakukan untuk mendapatkan data dan informasi tentang keefektifan model pembelajaran berbasis proyek dalam keterampilan berbicara bahasa Jerman Siswa Kelas X MIA SMA Negeri 2 Sungguminasa. Penelitian ini merupakan penelitian eksperimen semu yang menggunakan tes keterampilan berbicara dan perlakuannya menggunakan model pembelajaran berbasis proyek. Populasi yang digunakan dalam penelitian ini adalah seluruh siswa kelas X MIA SMA Negeri 2 Sungguminasa. Sampelnya adalah siswa kelas X MIA 2 berjumlah 30 siswa sebagai kelas eksperimen dan siswa kelas $X$ MIA 4 berjumlah 30 sebagai kelas kontrol. Teknik sampel yang digunakan ialah sampel acak. Pengujian hipotesis menggunakan rumus uji-t. Hasil analisis data menunjukkan bahwa $t_{h}(10,128)>t_{t}(2,002)$ dengan taraf alpha $(\alpha) 0,05$. Hasil penelitian menunjukkan bahwa model pembelajaran berbasis proyek efektif dalam keterampilan berbicara bahasa Jerman siswa kelas X MIA SMA Negeri 2 Sungguminasa.
\end{abstract}

Kata Kunci: Model Pembelajaran, Proyek, Keterampilan Berbicara, dan Bahasa Jerman

\begin{abstract}
This study was conducted to obtain data and information about the effectiveness of project-based learning model in the German speaking skill Class X MIA SMAN 2 Sungguminasa. This study is a quasi-experimental research that uses speaking skill test and treatment by using project-based learning model. The population used in this study were all students of class X MIA SMAN 2 Sungguminasa. The sample was class X MIA 2 which consisted of 30 students as an experimental class and 30 students in class X MIA 4 as control class. Sampling technique used was random sample. Hypothesis testing used $t$-test formula. The results of data analysis showed that $t_{h}(10.128)>t_{t}(2.002)$ with the level of alpha is $(\alpha) 0.05$. The results showed that the project-based learning model was effective in German speaking skill class X MIA SMAN 2 Sungguminasa.
\end{abstract}

Keywords: Learning Model, Project, Speaking Skill, and German Language.

\section{PENDAHULUAN}

Pada pembelajaran bahasa Jerman di sekolah menengah atas (SMA) terdapat empat kompetensi berbahasa yang dipelajari, yakni: kemampuan menyimak, kemampuan membaca, keterampilan berbicara dan keterampilan menulis, serta ditunjang oleh dua aspek yakni kemampuan kosakata dan tata bahasa.

Keterampilan berbahasa yang akan diteliti dalam penelitian ialah keterampilan berbicara. Melalui 
keterampilan berbicara, siswa dapat mengutarakan ide atau gagasan yang ada. Mengucapkan sesuatu dalam bahasa Jerman tidaklah mudah, karena ada banyak kata yang penyebutannya hampir sama, tetapi maknanya berbeda. Oleh karena itu, peneliti harus benar-benar teliti dengan pengucapan siswa agar tidak terjadi kesalahan.

Berdasarkan hasil observasi dan wawancara dengan guru bahasa Jerman di SMA Negeri 2 Sungguminasa diperoleh informasi bahwa siswa SMA Negeri 2 Sungguminasa masih kurang dalam keterampilan berbicara bahasa Jerman. Nilai dari hasil keterampilan berbicara masih di bawah standar atau masih kurang dari nilai Kriteria Ketuntasan Minimal (KKM). Nilai KKM bahasa Jerman di SMA Negeri 2 Sungguminasa ialah 70, sedangkan nilai yang didapatkan oleh siswa berdasarkan nilai harian dan ujian hariannya ialah hanya rata-rata 60 . Selain itu, hasil dari pengamatan peneliti, siswa yang berbicara dalam bahasa Jerman masih dipengaruhi bahasa pertamanya yaitu bahasa Makassar. Oleh karena itu, mereka masih perlu dilatih cara pengucapan dan intonasinya.

Sesuai dengan hasil observasi di atas, penelitian yang dilakukan oleh Azwar (2011:28) menyatakan bahwa keterampilan siswa dalam berbicara bahasa Jerman di SMA Negeri 1 Sungguminasa masih kurang dengan persentase $45 \%$. Adapun penelitian dari Gaffar (2013:iii) menyatakan bahwa keterampilan berbicara bahasa
Jerman siswa di SMK Negeri 6 Makassar dalam bidang perhotelan tergolong rendah dengan persentase $47.06 \%$. Selain pendapat tersebut, penelitian dari Kurniawati (2011:vi) menyatakan bahwa keterampilan berbicara siswa masih kurang dengan persentase $58,2 \%$.

Berdasarkan masalah-masalah yang ditemukan saat observasi dalam pembelajaran bahasa Jerman khususnya keterampilan berbicara, maka dalam pendidikan formal diperlukan pedoman atau kurikulum yang baik, sebab pengajaran yang dilakukan di sekolah berdasarkan kurikulum 2013. Pada tahun 2013 kementerian pendidikan telah mengubah kurikulum sekolah menjadi Kurikulum 2013. Kurikulum itulah yang dipakai saat ini dan melalui kurikulum itu terbentuk pula model pembelajaran yang diajarkan.

Keefektifan pembelajaran dalam keterampilan berbicara siswa dapat dilihat dengan menggunakan model pembelajaran yang baru. Model yang akan diterapkan dalam pembelajaran ini ialah model pembelajaran berbasis proyek. Melalui model pembelajaran tersebut, siswa diharapkan mampu membentuk suatu konstruksi proyek, dapat memecahkan masalah, dan menghasilkan suatu karya produk yang dilakukan secara berkelompok. Model pembelajaran ini sangat cocok untuk pembelajaran yang aktif dan membuat siswa lebih kreatif.

Sejalan dengan penelitian yang dilakukan oleh Oktaviani (2015) pada penelitiannya dalam mata pelajaran 
kimia menyatakan bahwa dalam menerapkan model pembelajaran berbasis proyek dapat berdampak sangat baik terhadap proses belajar siswa dengan persentase sebesar 93,5\% dan memberikan respon yang positif dalam pembelajaran berbasis proyek. Pendapat di atas senada dengan hasil penelitian Sudewi dkk (2013:1) pada penelitiannya dalam mata pelajaran IPS menyatakan bahwa model pembelajaran berbasis proyek dapat meningkatkan kemampuan berpikir kritis siswa dengan persentase $85 \%$ dan tanggapan siswa terhadap pembelajaran adalah positif. Selain itu, hasil penelitian Turyantana (2013:1) pada penelitian model pembelajaran berbasis proyek dalam menulis karya ilmiah bahasa Indonesia menyatakan bahwa siswa terlihat aktif dalam kegiatan pembelajaran dan tercapainya ketuntasan hasil belajar siswa dengan nilai rata-rata siswa ialah 79 .

\section{MODEL PEMBELAJARAN BERBASIS PROYEK}

Menurut Abidin (2014:117) model pembelajaran dapat diartikan sebagai suatu konsep yang membantu menjelaskan proses pembelajaran, baik menjelaskan pola pikir maupun pola tindakan pembelajaran tersebut.

Pembelajaran pada masa kini tidak lagi berpusat pada guru, melainkan berpusat pada siswa. Ini dilakukan untuk mengikuti Kurikulum 2013. Kurikulum 2013 memiliki beberapa model-model pembelajaran. Salah satunya yaitu model pembelajaran berbasis proyek dan dalam bahasa Inggris disebut Project Based Learning (PBL).

Pengertian model pembelajaran berbasis proyek dari Al-Tabany (2014:41) yaitu model pembelajaran yang melibatkan peserta didik dalam kegiatan pemecahan masalah dan memberi peluang peserta didik bekerja secara otonom mengkonstruksi belajar mereka sendiri, dan puncaknya menghasilkan produk karya siswa bernilai dan realistik.

Sani (2014:172) mengatakan bahwa PBL dapat didefinisikan sebagai sebuah pembelajaran dengan aktivitas jangka panjang yang melibatkan siswa dalam merancang, membuat, dan menampilkan produk untuk mengatasi permasalahan dunia nyata.

Senada dengan pendapat di atas, Majid \& Rochman (2014:162) menjelaskan bahwa pembelajaran berbasis proyek merupakan model pembelajaran yang menggunakan masalah sebagai langkah awal dalam mengumpulkan dan mengintegrasikan pengetahuan baru berdasarkan pengalamannya dalam beraktivitas.

Setiap model pembelajaran memiliki karakteristik tertentu. Karakteristik tersebut menunjukkan ciri-ciri model pembelajarannya dan tujuan pembelajaran yang akan dicapai. Model pembelajaran berbasis proyek memiliki karakteristik tertentu dan pembelajarannya berpusat pada siswa.

Al-Tabany (2014) menjelaskan karakteristik model pembelajaran 
berbasis proyek yang intisarinya sebagai berikut: (1) siswa membuat keputusan dan kerangka kerja; (2) siswa menemukan masalah; (3) siswa merancang proses kerja; (4) siswa mendapatkan dan mengolah informasi yang dikumpulkan; (5) siswa melakukan evaluasi; (6) siswa melihat pekerjaannya kembali secara teratur; (7) siswa menghasilkan sebuah produk dan dievaluasi kualitasnya; (8) adanya toleransi pada kesalahan dan perubahan di dalam kelas.

Dalam melaksanakan proses pembelajaran ini dilakukan secara sistematis untuk menyelesaikan suatu proyek. Berikut Langkah-langkah pembelajaran berbasis proyek menurut Sani (2014:181) yang intisarinya sebagai berikut: (1) penyajian suatu permasalahan. Permasalahan diajukan dalam bentuk pertanyaan;(2) membuat perencanaan. Guru perlu merencanakan standar kompetensi yang akan dikaji ketika membahas permasalahan; menyusun penjadwalan. Siswa harus pembuat penjadwalan pelaksanaan proyek yang disepakati bersama guru; (4) memonitor pembuatan proyek. Pelaksanaan pekerjaan siswa harus dimonitor dan difasilitasi prosesnya; (5) melakukan penilaian. Penilaian dilakukan secara autentik dan guru perlu memvariasikan jenis penilaian yang digunakan; (6) evaluasi. Memberikan kesempatan pada siswa dalam melakukan refleksi pembelajaran yang telah dilakukan baik secara individu maupun kelompok.
Model pembelajaran yang dilakukan oleh guru pasti memiliki kelebihan dan kekurangannya masing-masing. Tidak ada satupun model pembelajaran yang sangat bagus atau yang sangat jelek. Berikut diuraikan kelebihan dan kekurangan model pembelajaran berbasis proyek.

Kelebihan model pembelajaran berbasis proyek yang dikemukakan oleh Kemendikbud dalam Abidin (2014:171) yang intisarinya sebagai berikut: (1) meningkatkan motivasi belajar peserta didik untuk belajar; (2) meningkatkan kemampuan pemecahan masalah; (3) membuat peserta didik menjadi lebih aktif dalam belajar; (4) meningkatkan kolaborasi; (5) mendorong peserta didik untuk terampil berkomunikasi; (6) meningkatkan keterampilan peserta didik dalam mengelola sumber; (7) memberikan pengalaman kepada peserta didik pembelajaran dan praktik; (8) menyediakan pengalaman belajar yang melibatkan peserta didik; (9) melibatkan para peserta didik untuk belajar mengambil informasi dan pengetahuan yang hal tersebut kemudian diimplementasikan dengan dunia nyata; (10) membuat suasana belajar menjadi menyenangkan.

Selain kelebihan, model pembelajaran ini juga memiliki beberapa kelemahan. Menurut Sani (2014:177) kelemahan model pembelajaran berbasis proyek adalah (1) membutuhkan banyak waktu untuk menyelesaikan masalah dan menghasilkan produk; membutuhkan biaya yang cukup; (3) 
membutuhkan guru yang terampil dan mau belajar; (4) membutuhkan fasilitas, peralatan, dan bahan yang memadai; (5) tidak sesuai untuk siswa yang mudah menyerah dan tidak memiliki pengetahuan serta keterampilan yang dibutuhkan; (6) kesulitan melibatkan semua siswa dalam kerja kelompok.

\section{KETERAMPILAN BERBICARA}

Keterampilan merupakan kemampuan manusia dalam melakukan suatu kegiatan tertentu. Kegiatan berbahasa juga memerlukan keterampilan yang baik dan dilatih terus, agar dapat terampil dalam berbicara, menulis, dan sebagainya.

$$
\text { Pengertian keterampilan }
$$

menurut Mechling (Hoffmann, 2003:1) adalah sebuah komponen yang dapat diperoleh sendiri dari tindakan sadar manusia yang sebagian besar dibentuk melalui latihan. Pendapat di atas sepadan dengan Tarigan (2013:1) yang menyatakan bahwa keterampilan hanya dapat diperoleh dan dikuasai dengan jalan praktek dan banyak latihan.

Keterampilan yang diteliti dalam penelitian ini ialah berbicara. Berbicara merupakan suatu bentuk komunikasi dari seseorang ke orang lain untuk menyampaikan suatu pesan atau informasi. Dalam menyampaikan suatu pesan atau informasi kepada orang lain, memiliki keterampilan dalam berbicara sangat penting, agar pesan atau informasi yang disampaikan dapat dipahami oleh orang lain.
Menurut Harwanegg (2010:17) sebuah kegiatan berkomunikasi dimana seseorang berusaha membuat lawan bicaranya mengerti. Sehubungan dengan pendapat di atas, menurut Tarigan (2013:16) bahwa berbicara adalah kemampuan mengucapkan bunyi-bunyi artikulasi atau kata-kata untuk mengekspresikan, menyatakan atau menyampaikan pikiran, gagasan, dan perasaan.

Kemampuan berbahasa terdiri atas kemampuan reseptif dan kemampuan produktif. Keterampilan berbicara merupakan bagian dari kemampuan produktif. Dikatakan produktif, karena keterampilan berbicara dapat menyampaikan suatu gagasan, ungkapan dan ide kepada orang lain. Adapun pengertian keterampilan berbicara sebagai berikut.

Menurut Iskandarwassid dan Sunendar (2013:241) menyatakan bahwa keterampilan berbicara pada hakikatnya merupakan keterampilan mereproduksi arus sistem bunyi artikulasi untuk menyampaikan kehendak, kebutuhan perasaan dan keinginan kepada orang lain. Adapun pendapat tersebut dari Thau-Knudsen (2013) menyatakan bahwa keterampilan berbicara adalah kemampuan secara lisan yang menyatakan bahwa isi pernyataan pembicara ke pendengar dapat dimengerti.

Menurut Tarigan (2013:16) bahwa tujuan utama dari berbicara adalah untuk berkomunikasi. Agar dapat menyampaikan pikiran secara 
efektif, seyogianyalah sang pembicara memahami makna segala sesuatu yang ingin dikomunikasikan. Pendapat tersebut sepadan dengan pernyataan dari Ningsih, dkk (2014:4) yaitu tujuan utama dari berbicara adalah berkomunikasi dan berinteraksi dengan orang-orang yang ada di sekitarnya. Untuk dapat menyampaikan sebuah pesan atau informasi, perlu adanya saling pemahaman antara komunikator dan komunikan.

Dari pendapat di atas, disimpulkan bahwa tujuan berbicara adalah berkomunikasi kepada orang lain yang ada disekitarnya untuk memberitahukan sesuatu, menghibur, dan mempengaruhi pendengar.

\section{METODE PENELITIAN}

Jenis penelitian yang akan digunakan adalah penelitian eksperimen semu (quasi experiment) dengan desain kelompok kontrol prates-pascates berpasangan (matching pretest-posttest control group design) (Sukmadinata, 2015:207). Dalam penelitian ini terdapat dua kelompok yaitu kelas eksperimen yang menggunakan model pembelajaran berbasis proyek dan kelas kontrol yang menggunakan metode konvensional.

Dalam penelitian ini akan menggunakan tes keterampilan tingkat penerapan (C3). Tes ini akan dinilai dari cara siswa menerapkan kemampuan berbahasa Jerman dalam sebuah video yang berdurasi pendek. Tema yang dijadikan sebuah video ialah Sich Vorstellen.
Populasi dalam penelitian ini adalah siswa kelas $X$ MIA SMA Negeri 2 Sungguminasa yang terdiri 4 kelas yang berjumlah 125 siswa. Sampel yang akan digunakan dalam penelitian ini adalah siswa kelas $\mathrm{X}$ MIA 2 berjumlah 30 siswa yang dipilih sebagai kelas eksperimen dan X MIA 4 berjumlah 30 siswa yang dipilih sebagai kelas kontrol. Pemilihan sampel tersebut berdasarkan sampel acak/random.

Analisis data dalam penelitian ini akan menggunakan analisis statistik inferensial. Sebelum menguji hipotesis, terlebih dahulu menghitung rata-rata, varians dan simpangan baku, setelah itu data tersebut diuji normalitasnya dan homogenitas, kemudian menguji hipotesis dengan menggunakan uji-t.

\section{PEMBAHASAN}

Bagian ini dibahas mengenai hasil penelitian yang diperoleh dari analisis data penelitian tentang keefektifan model pembelajaran berbasis proyek dalam keterampilan berbicara bahasa Jerman siswa kelas $X \quad M I A \quad$ SMA Negeri 2 Sungguminasa. Perolehan skor yang telah dipaparkan sebelumnya memberikan gambaran bahwa skor yang diperoleh siswa yang belajar dengan menggunakan model pembelajaran berbasis proyek lebih tinggi dibandingkan dengan siswa yang belajar dengan menggunakan pembelajaran konvensional dalam keterampilan berbicara bahasa Jerman pada SMA Negeri 2 Sungguminasa. 
Pada penelitian ini, pembelajaran dilakukan selama empat kali pertemuan setelah pemberian pre-test di kedua kelas. Pada kelas eksperiman siswa diajar dengan menggunakan model pembelajaran berbasis proyek, sedangkan kelas kontrol diajar menggunakan pembelajaran konvensional.

Sesuai dengan hasil pre-test siswa di kelas X MIA 2 sebagai kelas eksperimen menunjukkan bahwa nilai rata-rata (mean) keterampilan berbicara siswa adalah 54,3 dan masih dikategori cukup yang nilai tertingginya ialah 73 dan nilai terendahnya ialah 46. Berdasarkan data distribusi frekuensi dan persentase, nilai yang paling banyak diperoleh oleh siswa ialah nilai antara 46-50 sebanyak 13 siswa atau $43,33 \%$.

Hasil pre-test siswa di kelas $\mathrm{X}$ MIA 4 sebagai kelas kontrol menunjukkan nilai rata-rata (mean) keterampilan berbicara siswa adalah 49,67 dan nilainya dikategori kurang yang nilai tertinggi adalah 70 dan nilai terendah adalah 43. Berdasarkan data distribusi frekuensi dan persentase, nilai yang paling banyak diperoleh siswa adalah nilai antara 43-47 sebanyak 17 siswa atau $56,67 \%$.

Berdasarkan nilai rata-rata siswa kelas eksperimen dan siswa kelas kontrol, bila dibandingkan yaitu $54,3>49,67$ dan selisihnya sebanyak 4,6. Perbandingan dari kelas eksperimen dan kelas kontrol memiliki perbedaan yang kecil. Dengan demikian, nilai rata-rata siswa kelas eksperimen dan nilai ratarata siswa kelas kontrol tidak memiliki perbedaan yang signifikan karena perbedaan kecil yaitu 4,6, yang berarti tingkat pemahaman siswa terhadap mata pelajaran bahasa Jerman di kelas eksperimen dan kelas kontrol sama (homogen).

Selain hasil statistik di atas, kedua kelas menunjukkan juga bahwa nilai rata-rata siswa masih di bawah nilai Kriteria Kelulusan Minimal (KKM) di sekolah yaitu 70. Hal ini disebabkan oleh kurangnya motivasi dan minat siswa dalam berbahasa Jerman dan kurangnya penguasaan kosakata dalam merangkai kalimat sederhana, sehingga komunikasi kurang lancar dan terkadang menggunakan kosakata bahasa Inggris, seperti kata Brother yang seharusnya Bruder. Siswa menggunakan kata "Brother", karena siswa sudah terbiasa dengan kata tersebut dan belum tahu apa sebutannya dalam bahasa Jerman. Selain itu, disebabkan pula pada kesulitan pengucapan seperti huruf umlaut, salah satunya huruf " ä " yang tetap dibaca seperti huruf "a" biasa, dan pengucapan "eu" seperti neun, yang seharusnya diucap "noin" tetap diucap "neun". Siswa tidak mengetahui cara baca huruf vokal yang ada umlautnya dan huruf diftong, sehingga mereka membacanya seperti penyebutan biasa. Serta, siswa jarang mendengarkan audio atau video berbahasa Jerman yang disebabkan oleh kurangnya fasilitas sekolah seperti laboratorium bahasa. 
Setelah dilakukan pembelajaran dengan model pembelajaran berbasis proyek pada kelas eksperimen dan pembelajaran konvensional di kelas kontrol, diberikan tes akhir (post-test) untuk kedua kelas. Tes akhir (posttest) ini dilakukan untuk melihat apakah ada perbedaan yang signifikan antara model pembelajaran berbasis proyek dengan pembelajaran konvensional.

Berdasarkan dengan hasil posttest siswa di kelas kelas X MIA 2 sebagai kelas eksperimen menunjukkan bahwa nilai rata-rata (mean) keterampilan berbicara siswa adalah 73,17 dan dikategori baik yang nilai tertingginya ialah 83 dan nilai terendahnya ialah 56. Berdasarkan data distribusi frekuensi dan persentase, nilai yang paling banyak diperoleh oleh siswa ialah nilai antara 76-80 sebanyak 13 siswa atau $43,33 \%$.

Berdasarkan hasil post-test siswa di kelas X MIA 4 sebagai kelas kontrol menunjukkan nilai rata-rata (mean) keterampilan berbicara siswa adalah 57,3 dan nilainya dikategori cukup yang nilai tertinggi adalah 70 dan nilai terendah adalah 43. Berdasarkan data distribusi frekuensi dan persentase, nilai yang paling banyak diperoleh siswa adalah nilai antara 53-57 sebanyak 12 siswa atau $40 \%$.

Sesuai dengan nilai rata-rata siswa kelas eksperimen dan siswa kelas kontrol, bila dibandingkan yaitu 73,17 > 57,3 dan selisihnya sebanyak 15,87. Perbandingan dari kelas eksperimen dan kelas kontrol memiliki perbedaan yang besar. Dengan demikian, nilai rata-rata siswa kelas eksperimen dan nilai ratarata siswa kelas kontrol memiliki perbedaan yang signifikan karena perbedaan besar yaitu 15,87, yang berarti model pembelajaran berbasis proyek lebih baik dari pembelajaran konvensional.

Sesuai dengan hasil post-test siswa di kelas eksperimen yang menunjukkan bahwa nilai rata-rata siswa telah memenuhi nilai KKM. Hal ini dapat membuktikan bahwa model pembelajaran berbasis proyek dapat meningkatkan keterampilan berbicara siswa dan motivasi siswa dalam belajar bahasa Jerman. Pendekatan yang dilakukan di kelas yakni berpusat pada siswa, sehingga siswa tidak bosan belajar dalam kelas.

Dari hasil post-test kelas kontrol menunjukkan pula bahwa nilai rata-rata siswa masih di bawah nilai KKM. Hal ini disebabkan oleh metode pembelajaran yang digunakan guru tidak bervariasi (monoton), serta hanya mengacu pada satu sumber buku yaitu buku Ich Liebe Deutsch dan jarang menggunakan media belajar seperti media audio dalam proses pembelajaran. Selain itu, pendekatan pembelajaran yang dilakukan di kelas masih berpusat pada guru, hal ini terlihat pada saat peneliti melakukan observasi yaitu guru menjelaskan materi dalam buku, kemudian memberikan tugas yang ada pada buku kepada siswa.

Sebelum dilakukan pengujian hipotesis, terlebih dahulu dilakukan pengujian homogenitas. Dalam uji 
homogenitas, data yang diambil adalah hasil pre-test siswa di kelas eksperimen dan kelas kontrol. Tujuannya ialah untuk mengetahui kemampuan awal siswa. Pada kelas eksperimen menunjukkan varians yaitu 49,89, sedangkan varians kelas kontrol yaitu 48.23. Sesuai dengan kriteria pengujiannya, hasilnya ialah $F_{\text {hitung }}$ lebih kecil dari $F_{\text {tabel }}$ yakni F hitung 1,66 $<\mathrm{F}_{\text {tabel }}$ 5,050, sehingga dapat disimpulkan bahwa kedua sampel pre-test tersebut dinyatakan homogen.

Setelah pengujian homogenitas, dilakukan pula uji normalitas data. Dalam pengujian normalitas, data yang diambil ialah data nilai pre-test dan post-test siswa di kelas eksperimen dan kelas kontrol. Pengujian ini dilakukan untuk melihat apakah data yang diperoleh berdistribusi normal atau tidak.

Hasil uji normalitas data pretest kelas eksperimen menunjukkan bahwa data kelas eksperimen memiliki kai kuadrat hitung yang lebih kecil dari kai kuadrat tabel, $X_{\text {hitung }}<X_{\text {tabel }}$ yaitu $-78,61<11.07$. Hasil tersebut menunjukkan bahwa data kelas eksperimen dinyatakan normal.

Hasil uji normalitas data pretest kelas kontrol menunjukkan bahwa data kelas eksperimen memiliki kai kuadrat hitung yang lebih kecil dari kai kuadrat tabel, $X_{\text {hitung }}<X_{\text {tabel }}$ yaitu $-38,88<11.07$, sehingga data tersebut dinyatakan normal.

Hasil uji normalitas data posttest kelas eksperimen menunjukkan bahwa data kelas eksperimen memiliki kai kuadrat hitung yang lebih kecil dari kai kuadrat tabel, $X_{\text {hitung }}<X_{\text {tabel }}$ yaitu $-125,15<11.07$. Hasil tersebut menunjukkan bahwa data kelas eksperimen dinyatakan normal.

Hasil uji normalitas data posttest kelas kontrol menunjukkan bahwa data kelas eksperimen memiliki kai kuadrat hitung yang lebih kecil dari kai kuadrat tabel, $X_{\text {hitung }}<X_{\text {tabel }}$ yaitu $-71,92<11.07$, sehingga data tersebut dinyatakan normal.

Setelah hasil analisis di atas, dilanjutkan dengan uji-t untuk melihat hasil akhir penelitian ini. Hasilnya adalah thitung 10,128> $\mathrm{t}_{\text {tabel }} 2,002$. Sesuai dengan kriteria pengujian hipotesis yakni tolak $\mathrm{H}_{0}$ jika $\mathrm{t}_{\text {hitung }}>$ $\mathrm{t}_{\text {tabel}}$, maka $\mathrm{H}_{0}$ yang dalam penelitian ini adalah tidak ada perbedaan yang signifikan dalam keterampilan berbicara bahasa Jerman yang menggunakan model pembelajaran berbasis proyek siswa yang menggunakan metode konvensional dinyatakan ditolak. Jika $\mathrm{H}_{0}$ ditolak, maka $\mathrm{H}_{1}$ diterima, yakni adanya perbedaan yang signifikan dalam keterampilan berbicara bahasa Jerman antara siswa yang menggunakan model pembelajaran berbasis proyek dengan siswa yang menggunakan metode konvensional.

\section{KESIMPULAN}

Berdasarkan hasil analisis data yang telah diuraikan pada bagian sebelumnya, dapat disimpulkan bahwa model pembelajaran berbasis 
proyek efektif dalam keterampilan berbicara bahasa Jerman siswa kelas $X \quad$ MIA SMA Negeri 2 Sungguminasa. Hal tersebut dibuktikan dengan hasil analisis data yang telah dilakukan, dengan nilai post-test sebanyak 60 siswa setelah dilakukan uji-t pada masing-masing kelompok dengan hasil analisis data yaitu $t_{\text {hitung }} 10,128>t_{\text {tabel }} 2,002$ pada taraf signifikansi 0,05.

\section{DAFTAR PUSTAKA}

Abidin, Yunus. 2014. Desain Sistem Pembelajaran Dalam Konteks Kurikulum 2013. Bandung: PT Refika Aditama.

Al-Tabany, Trianto Ibnu Badar. 2014. Mendesain Model Pembelajaran Inovatif, Progresif, dan Kontekstual. Jakarta: Prenadamedia Group.

Arifin, Zainal. 2014. Penelitian Pendidikan. Bandung: PT Remaja Rosdakarya.

Azwar, M. 2011. Peningkatan Keterampilan Berbicara Siswa SMA Negeri 1 Sungguminasa Melalui Pembelajaran Kontekstual. Makassar: UNM. Skripsi.

Gaffar, Umar. 2013. Kemampuan Berbicara Bahasa Jerman Dalam Bidang Perhotelan Siswa SMK Negeri 6 Makassar. Makassar: UNM. Skripsi.

Harwanegg, Cornelia. 2010. Richtiges Sprechen in Alltag und Beruf: Warum gute Aussprache unser
Selbstbewusstein

stärkt.Books on Demand.

Iskandarwassid \& Sunenda, Dadang. $2013 . \quad$ Strategi

Pembelajaran Bahasa.

Bandung: Remaja

Rosdakarya.

Kosasih, E. 2014. Strategi Belajar dan Pembelajaran

Implementasi Kurikulum 2013. Bandung: Yrama Widya.

Kurniawati, Nia. 2011. Penerapan Metode Rollenspiel Untuk Mengingkatkan

Keterampilan Berbicara Bahasa Jerman Pada Siswa Kelas XI SMA Negeri 1 Sungguminasa. Makassar: UNM. Skripsi.

Majid, Abdul \& Rochman, Chaerul. 2014. Pendekatan Ilmiah Dalam Implementasi Kurikulum 2013. Bandung: Remaja Rosdakarya.

Ningsih, Lilik, dkk. 2014. Peningkatan Keterampilan Berbicara Melalui Kartu Gambar Berseri Dalam Pembelajaran Bahasa Indonesia Pada Murid Kelas IV, (Online), (http://jurnal.untan.ac.id/in dex.php/jpdpb/article/ viewFile/4849/4926, diakses 11 Januari 2016).

Nurgiyantoro,Burhan.

2012. Penilaian Dalam Pengajaran Bahasa dan Sastra. Yogyakarta: BPFE.

Oktaviani, Coryna. 2015. Penerapan Model Pembelajaran Berbasis Proyek Pada Materi Indikator Alami Di Kelas XI IPA SMAN 4 
Banda Aceh. Banda Aceh: UNSYIAH. Skripsi.

Sani, Ridwan Abdullah. 2014 Pembelajaran Saintifik Untuk Implementasi Kurikulum 2013. Jakarta: Bumi Aksara.

Sudewi, dkk. 2013. Penerapan Model Pembelajaran Berbasis Proyek Untuk Meningkatkan Kemampuan Berpikir Kritis Pada Siswa Kelas X Multimedia 3 SMK Negeri 1 Sukasada, (Online), Vol.3, (http://pasca.undiksha.ac.id le-

journal/index.php/jurnal_tp /article/view/ 1038/786 , diakses 17 Oktober 2015).

Sukmadinata, Nana Syaodih. 2015. Metode Penelitian Pendidikan. Jakarta: Kencana.

Tarigan, Henry Guntur. 2013. Berbicara Sebagai Suatu
Keterampilan Berbahasa. Bandung: Angkasa.

Thau-Knudsen, $\quad$ Erik. 2013. Sprechfertigkeit in handelndem Sprachband, (Online), (http://www.thauknudsen.dk/dokumenter/int erne/index.php?id=544, diakses 10 Januari 2016).

Thoifah, I'anatut. 2015. Statistika Pendidikan dan Metode Penelitian Kuantitatif. Malang: Madani.

Turyantana, I Ketut. 2013. Penerapan Model Pembelajaran Berbasis Proyek Untuk Meningkatkan Aktivitas Dan Tercapainya Ketuntasan Hasil Belajar Menulis Karya Ilmiah Siswa Kelas XI SMA Saraswati Seririt, (Online), Vol.1, No.2, (http://ejournal.undiksha.ac .id/index.php /JJPBS/article /view/ 363, diakses 17 Oktober 2015). 